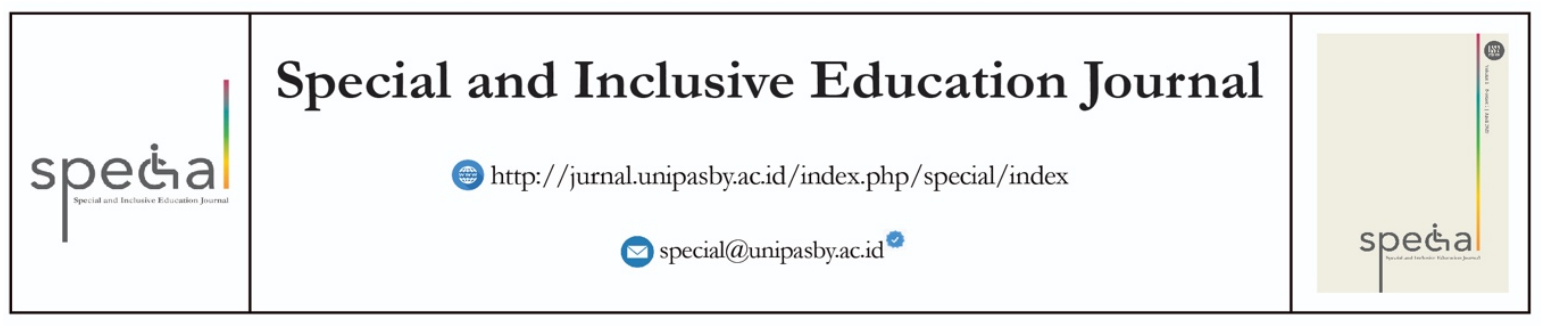

\title{
Implementasi Model Blended Learning terhadap Pemahaman Mata Kuliah Pembelajaran IPA bagi Mahasiswa Berkebutuhan Khusus pada Kelas Inklusi di Perguruan Tinggi
}

\author{
Mahardika Supratiwi $^{1}$, Munawir Yusuf $^{2}$, Subagya $^{3}$, Arsy Anggrellanggi $^{4}$, Tias Martika $^{5}$ \\ mahardika.s@staff.uns.ac.id | munawiryusuf@staff.uns.ac.id $\mid$ subagya60@staff.uns.ac.id $\mid$ \\ arsy@staff.uns.ac.id $\mid \underline{\text { tiasmartika uns@staff.uns.ac.id }}$
}

Pendidikan Luar Biasa/Pendidikan Khusus - Universitas Negeri Sebelas Maret

Jl. Ir. Sutami No.36 A, Pucangsawit, Kec. Jebres, Kota Surakarta, Jawa Tengah, 57126

\begin{tabular}{l}
\hline Artikel Info \\
\hline Koresponden penulis : \\
Mahardika Supartiwi \\
mahardika.s@staff.uns.ac.id
\end{tabular}

- Diterima 26 Januari 2020

- Direview 3 Maret 2020

- Disetujui 3 Maret 2020

- Dipublikasi 29 April 2020

\section{Kata Kunci:}

Mahasiswa Berkebutuhan Khusus; Blended Learning; Inklusi; Perguruan Tinggi

Keywords:

Disabled Students; Blended Learning; Inclusive, Higher Education

\begin{abstract}
Absstrak
Penelitian ini bertujuan untuk mengetahui pengaruh model blended learning terhadap pemahaman materi pada mata kuliah Pembelajaran IPA bagi ABK pada kelas inklusi di perguruan tinggi. Rancangan penelitian yang digunakan dalam penelitian ini adalah desain eksperimen kuasi One Group Pretest-Posttest Design. Subjek penelitian ini berjumlah 38 orang mahasiswa yang sedang menempuh mata kuliah Pembelajaran IPA bagi $\mathrm{ABK}$ pada kelas inklusi di perguruan tinggi. Dua di antara subjek tersebut adalah mahasiswa berkebutuhan khusus tunanetra dan tunarungu. Pengukuran terhadap pemahaman materi dilakukan sebanyak dua kali, yaitu sebelum dan sesudah penerapan blended learning diberikan. Hasil yang didapatkan dianalisis menggunakan paired t-test. Berdasarkan hasil analisis didapatkan bahwa terdapat kenaikan rata-rata skor pretes $(65,16)$ dan skor posttes $(73,87)$, dengan nilai $t=-9,321$ dengan $p=0,0001(p<0,05)$. Berdasarkan hasil tersebut dapat disimpulkan bahwa terdapat pengaruh yang signifikan pada penerapan blended learning terhadap peningkatan pemahaman mata kuliah Pembelajaran IPA bagi ABK pada kelas inklusi di perguruan tinggi.

Abstarct
This study aims to determine the effect of the blended learning model on
the understanding of the material in natural sciences learning courses for
disabled students in inclusive classes in higher education. The research
design used in this study was the experimental design of one group pre-
test and post-test design. The subjects of this study were 38 students who
were taking science learning courses for special needs students in inclusive
classes at higher education. Two of these subjects are students with special
needs who are blind and deaf. Measurement of material understanding is
done twice, that is before and after the application of blended learning is
given. The results obtained were analyzed using the paired t-test. Based on
the results of the analysis found that there was an increase in the average
pre-test score $(65.16)$ and post-test score $(73.87)$, with a value of $t=-9.332$
with $p=0.0001$ ( $p<0.05)$. Based on these results it can be concluded that
there is a significant influence on the application of blended learning to
increase understanding of natural science learning courses for disabled
students in inclusive classes in a higher education.
\end{abstract}




\section{PENDAHULUAN}

Pendidikan merupakan faktor penting dalam meningkatkan sumber daya manusia (SDM) pada suatu bangsa. Terlebih lagi dengan bertambah pesatnya perkembangan ilmu pengetahuan dan teknologi (IPTEK) saat ini, peran pendidikan menjadi semakin penting dalam upaya peningkatan SDM bangsa. Proses pembelajaran yang dilakukan dalam pendidikan biasanya dilakukan secara tatap muka antara pengajar dan peserta didik (siswa). Namun, pembelajaran tatap muka tersebut membuat sebagian siswa merasa bosan untuk belajar di dalam kelas (Wardani, Toenlioe, \& Wedi, 2018). Jika hal tersebut sering terjadi di kelas, maka dimungkinkan proses pembelajaran akan mengalami hambatan dan tidak dapat mencapai target optimal untuk meningkatkan SDM bangsa.

Menanggulangi permasalahan tersebut, muncul alternatif model pembelajaran dengan memanfaatkan teknologi dalam proses pembelajaran yaitu biasa disebut dengan pembelajaran elektronik atau e-learning. Model e-learning ini berpengaruh pada terjadinya proses transformasi pendidikan dari tradisional ke dalam bentuk digital, baik dalam hal konten maupun secara sistem (Wahono dalam Fandianta, Sanjaya, \& Widyandana, 2013). Pembelajaran menggunakan e-learning diperlukan untuk meningkatkan pemerataan dan akses pendidikan di Indonesia karena siswa dapat mengakses sumber belajar dari mana saja dan melalui perangkat digital, termasuk melalui smartphone yang dimiliki. Hal ini juga didukung dengan bertambahnya jaringan internet yang disediakan oleh berbagai provider telekomunikasi di seluruh Indonesia.

Model e-learning ini memang memiliki kelebihan-kelebihan yang dapat digunakan untuk mengatasi kekurangan pada pembelajaran tradisional (tatap muka). Meskipun demikian, berdasarkan penelitian Haryanto (2018) didapatkan bahwa dibutuhkan banyak kuota internet jika pengajar mengunggah konten video dan siswa mengunduh konten video tersebut. Selain itu, interaksi secara langsung antara pengajar dan siswa akan sangat berkurang sehingga peningkatan aspek sosial siswa menjadi tidak optimal. Padahal salah satu tujuan pembelajaran adalah untuk meningkatkan aspek sosial siswanya.

Berdasarkan beberapa kelemahan e-learning tersebut, maka para ahli pendidikan mulai mengembangkan model pembelajaran lain dengan memadukan proses tatap muka dan penggunakan e-learning dalam pembelajarannya, atau disebut juga dengan blended learning. Akkoyunlu dan Soylu (2008) menjelaskan bahwa pembelajaran campuran atau blended learning merupakan pembelajaran yang mengkombinasikan antara pembelajaran online dengan pembelajaran tatap muka. Secara umum, blended learning memiliki tiga makna antara lain integrasi pembelajaran tradisional dengan online learning, kombinasi media dan peralatan, dan kombinasi dari sejumlah pendekatan belajar mengajar terlepas dari teknologi yang digunakan. Pada dasarnya, penggunaan model blended learning merupakan model baru untuk kegiatan pembelajaran di perguruan tinggi. Pemilihan blended learning dipilih antara lain untuk meningkatkan akses dan fleksibilitas pembelajaran dan meningkatkan efektivitas biaya. Model 
blended learning ini berisi berbagai aktivitas kegiatan, termasuk belajar tatap muka, e-learning, dan kegiatan belajar mandiri.

Blended learning mempunyai kerangka dasar pengembangan konsep yang didasari oleh perspektif pembelajaran konstruktivistik dengan memberikan pengalaman dengan penyelidikan yang memastikan konsep dibangun dan berasimilasi secara mendalam dan bermakna (Garrison \& Vaughan, 2008). Picciano \& Seaman (dalam Fardhany, 2016) membagi model pembelajaran secara umum menjadi empat kelompok yaitu tradisional, web facilitated, blended dan online/e-learning sesuai dengan presentase sumber belajar berbasis web.

Model tradisional merupakan pembelajaran tanpa memanfaatkan fasilitas online (persentase $0 \%$ atau tidak berbasis web), di mana perangkat pembelajaran dibawa di kelas dan pembelajaran berbasis tatap muka. Model web facilitated merupakan pemanfaatan web dalam proses pembelajaran untuk membantu peningkatan penguasaan bahan ajar yang tidak terpenuhi dalam proses tatap muka (pemberian materi tambahan melalui web). Pada pemanfaatannya lebih banyak dalam pengumpulan tugas (assignment), model ini memiliki persentase sumber belajar berbasis web sebesar 1-29\%. Selanjutnya model blended learning memiliki persentase 30-79\% di mana proses pembelajarannya menggunakan kombinasi antara bahan ajar berbeasis web dan tatap muka. Model terakhir adalah model e-leaming (100\% pembelajaran berbasis web) di mana seluruh pembelajaran melalui online dan tidak ada pembelajaran tatap muka.

Penerapan model blended learning ini telah dilakukan dalam beberapa penelitian. Fandianta dkk. (2018) melakukan penelitian mengenai penerapan blended learning untuk meningkatkan pengetahuan mahasiswa Politeknik Kesehatan. Pada penelitian tersebut didapatkan hasil bahwa blended learning mampu meningkatkan pengetahuan subjek penelitiannya. Penelitian selanjutnya dilakukan oleh Sjukur (2012) yang menemukan bahwa blended learning dapat meningkatkan motivasi belajar dan hasil belajar siswa tingkat SMK. Rizkiyah (2015) juga melakukan penerapan blended learning untuk meningkatkan hasil belajar siswa pada mata pelajaran ilmu bangunan di SMK dan hasilnya menunjukkan bahwa hasil belajar siswa meningkat. Berdasarkan beberapa penelitian tersebut diketahui bahwa blended learning dapat digunakan untuk meningkatkan pemahaman dan pengetahuan pada proses pembelajaran yang dilakukan di kelas. (Jauhari \& Dewi, 2019) penerapan blanded learning dapat meningkatkan capaian pembelajaran mahasiswa berkebutuhan khusus.

Bertolak dari beberapa penelitian dan penjelasan di atas, maka dalam penelitian ini dilakukan penerapan model blended learning untuk meningkatkan pemahaman mahasiswa terhadap mata kuliah Pembelajaran IPA bagi Anak Berkebutuhan Khusus (ABK) pada kelas inklusi di Program Studi Pendidikan Khusus Universitas Sebelas Maret (Prodi PKh UNS). UNS merupakan salah satu perguruan tinggi inklusif yang menerima mahasiswa berkebutuhan khusus. Pendidikan inklusif merupakan sebuah layanan pendidikan bagi peserta didik yang memiliki kebutuhan khusus di penyelenggara pendidikan reguler (Staub \& Peck dalam Tarmansyah, 2007). Pada sekolah atau instansi pendidikan penyelenggara inklusif ini menempatkan individu berkebutuhan khusus ke dalam 
sekolah reguler dan menempuh pembelajaran bersama-sama dengan individu yang tidak berkebutuhan khusus.

Selama ini UNS telah menerima dan meluluskan mahasiswa-mahasiswa berkebutuhan khusus diantaranya dengan kebutuhan khusus tunanetra dan tunarungu. Dibutuhkan strategi dan model pembelajaran tersendiri bagi individu berkebutuhan khusus dengan menyesuaikan karakteristik kebutuhan khusus individu tersebut (Dermawan, 2013). Model blended learning dapat menjadi salah satu alternatif model pembelajaran yang dapat diterapkan pada kelas-kelas inklusi di perguruan tinggi. Hal tersebut didukung dengan portal pembelajaran daring UNS yang disebut dengan SPADA UNS.

Melalui SPADA UNS, pengajar (dosen) dapat mengunggah materi dan tugas perkuliahan pada akun SPADA miliknya dan membagikan link materi tersebut bagi mahasiswa. Mahasiswa yang mengikuti perkuliahan tersebut dapat mengakses materi dan tugas perkuliahan melalui portal tersebut. Mengadopsi model blended learning, maka dalam penelitian ini dilakukan pembelajaran campuran secara tatap muka dan pembelajaran daring. Tujuan penelitian ini adalah untuk mengetahui pengaruh model blended learning terhadap pemahaman materi pada mata kuliah Pembelajaran IPA bagi ABK pada kelas inklusi di perguruan tinggi.

\section{METODE PENELITIAN}

Rancangan penelitian ini menggunakan desain eksperimen kuasi One Group Pretest-Posttest Design. Desain ini menggunakan satu kelompok eksperimen yang dikenai perlakuan berupa penerapan blended learning. Dilakukan pengukuran terhadap pemahaman materi mata kuliah Pembelajaran IPA bagi ABK pada saat sebelum (pretest) dan setelah (posttest) penerapan blended learning. Subjek penelitian ini berjumlah 38 orang mahasiswa Prodi PKh UNS yang sedang menempuh mata kuliah Pembelajaran IPA bagi ABK. Dua di antaranya adalah mahasiswa berkebutuhan khusus, satu tunanetra dan satu tunarungu. Pengukuran pemahaman materi dilakukan dengan menggunakan tes prestasi berupa tes tulis. Data yang berhasil terkumpul dianalisis menggunakan teknik analisis paired t-test.

\section{HASIL DAN PEMBAHASAN}

Berdasarkan hasil analisis data, didapatkan bahwa sebelum penerapan blended learning dapatkan nilai rata-rata pemahaman materi sebesar 65,16, sedangkan setelah dilakukan penerapan blended learning rata-rata pemahaman mahasiswa naik menjadi 73,87 . Hasil tersebut menunjukkan bahwa terjadi kenaikan rata-rata skor dari sebelum penerapan blended learning dan setelah penerapan blended learning. Rata-rata skor pretest dan posttest dapat dilihat pada gambar berikut: 


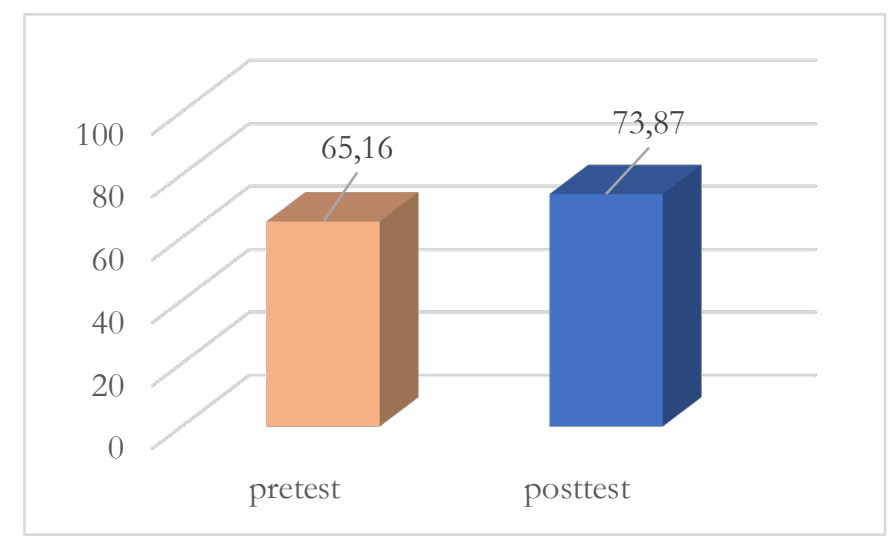

Gambar 1. Perbandingan rata-rata skor pretes dan posttes pemahaman materi

Data yang telah diperoleh kemudian dianalisis menggunakan paired $t$-test dan didapatkan hasil $\mathrm{t}=$ 9,321 dengan $\mathrm{p}=0,0001 \quad(\mathrm{p}<0,05)$. Hasil tersebut menunjukkan bahwa terdapat pengaruh yang signifikan dalam penerapan blended learning dalam meningkatkan pemahaman materi mata kuliah Pembelajaran IPA bagi ABK di kelas inklusi. Nilai t hitung yang negatif menandakan bahwa terjadi kenaikan skor dari kondisi sebelum perlakuan dan kondisi setelah perlakuan. Hasil uji paired t-test selengkapnya dapat dilihat pada Tabel 1 berikut ini.

Tabel 1. Uji paired t-test

\begin{tabular}{|c|c|c|c|c|c|c|c|}
\hline \multicolumn{5}{|c|}{ Paired Differences } & \multirow[b]{3}{*}{$\mathrm{t}$} & \multirow[b]{3}{*}{$\mathrm{df}$} & \multirow[b]{3}{*}{ Sig. (2-tailed) } \\
\hline \multirow[b]{2}{*}{ Mean } & \multirow{2}{*}{$\begin{array}{c}\text { Std. } \\
\text { Deviation }\end{array}$} & \multirow{2}{*}{$\begin{array}{c}\text { Std. Error } \\
\text { Mean }\end{array}$} & \multicolumn{2}{|c|}{$\begin{array}{c}95 \% \text { Confidence Interval of } \\
\text { the Difference }\end{array}$} & & & \\
\hline & & & Lower & Upper & & & \\
\hline-8.711 & 5.761 & .934 & -10.604 & -6.817 & -9.321 & 37 & .000 \\
\hline
\end{tabular}

Hasil penelitian menunjukkan bahwa penerapan blended learning dapat meningkatkan pemahaman materi mata kuliah Pembelajaran IPA bagi ABK di kelas inklusi Prodi PKh UNS. Hal tersebut memperlihatkan bahwa melalui model blended learning, mahasiswa memiliki kesempatan lebih banyak untuk mempelajari materi tidak hanya melalui pembelajaran tatap muka tetapi juga melalui pembelajaran daring.

Mahasiswa berkebutuhan khusus tunanetra dan tunarungu juga dapat lebih mengikuti pembelajaran dengan baik karena dapat mengakses kembali materi-materi perkuliahan yang ada dalam SPADA UNS. Jika dilakukan hanya melalui pembelajaran tatap muka, maka mahasiswa-mahasiswa berkebutuhan khusus tersebut tidak dapat mengulang kembali pembelajaran yang telah didapatkan. Oleh karena itu, model blended learning memiliki kelebihan-kelebihan jika diterapkan dalam kelas inklusif di perguruan tinggi. 
Sejalan yang diungkapkan oleh Idris (2011), bahwa keuntungan model blended learning dapat memberikan kemudahan implementasi pembelajaran, baik bagi pengajar maupun peserta didik. Selain itu, keuntungan lainnya adalah adanya efisiensi biaya dalam proses pembelajaran. Keuntungan berikutnya adalah hasil pembelajaran lebih optimal, menyesuaikan berbagai kebutuhan peserta didik, dan meningkatkan daya tarik pembelajaran.

\section{KESIMPULAN}

Berdasarkan analisis hasil penelitian dan pembahasan maka dapat disimpulkan bahwa penerapan blended learning dapat digunakan untuk meningkatkan pemahaman materi mata kuliah Pembelajaran IPA bagi ABK pada kelas inklusi di Prodi PKh UNS.

\section{DAFTAR PUSTAKA}

Akkayonlu, B., \& Soylu, M. Y. (2008). A Study of Student's Perceptions in a Blended Learning Environment Based on Different Learning Styles. Ducational Technology \& Society, 11 (1), 183 193.

Dermawan, O. (2013). Strategi Pembelajaran bagi Anak Berkebutuhan Khusus di SLB. Psymphatic Jurnal Ilmiah Psikologi, 6 (2), 886-897.

Fandianta, Sanjaya, G. Y., \& Widyandana. (2013). Meningkatkan Pengetahuan Mahasiswa dengan Memberikan Fleksibilitas Belajar Mengajar Melalui Metode Blended Learning. Jurnal Pendidikan Kedokteran Indonesia, 2 (2), 1-8.

Fardhany, P. H. (2016). Pemanfaatan Baban Ajar Berbasis Blended Learning dalam Pendidikan Jasmani Olahraga dan Kesehatan. Makalah disampaikan dalam Prosiding Seminar Nasional peran Pendidikan Jasmani dalam Menyangga Interdisipliner Ilmu Keolahragaan 2016, Universitas Negeri Malang (hal. 456-471).

Garrison, D. R., \& Vaughan, N. D. (2008). Blended Learning in Higher Education: Framework, Principles, and Guidelines. San Fransisco: Jossey-Bass.

Haryanto, S. (2018). Kelebihan dan Kekurangan e-learning Berbasis Schoology (Studi PTK dalam Pembelajaran Mata Kuliah Academic Listening). Makalah disampaikan dalam Prosiding Seminar Nasional Geotik 2018, Universitas Muhammadiyah Surakarta (hal. 106-110).

Idris, H. (2011). Pembelajaran Model Blended Learning. Jurnal Iqra', 5 (1), 61-73.

Jauhari, M. N., \& Dewi, D. P. (2019). Pelaksanaan Cooperative Learning Model Pada Mata Kuliah Media Pembelajaran ABK Bagi Mahasiswa Berkebutuhan Khusus Prodi Pendidikan Khusus Fkip Universitas PGRI Adibuana Surabaya. Buana Pendidikan: Jurnal Fakultas Keguruan Dan Ilmu Pendidikan, 15(27), 79-89. 
Rizkiyah, A. (2015). Penerapan Blended Learning untuk Meningkatkan Hasil Belajar Siswa pada Mata Pelajaran Ilmu Bangunan di Kelas X TGB SMK Negeri 7 Surabaya. Jumal Kajian Pendidikan Teknik Bangunan, 1 (1), 40-49.

Sjukur, S. B. (2012). Pengaruh Blended Learning terhadap Motivasi Belajar dan Hasil Belajar Siswa Tingkat SMK. Jurnal Pendidikan Vokasi, 2 (3), 368-378.

Wardani, D. N., Toenlioe, A. J. E., \& Wedi, A. (2018). Daya tarik pembelajaran di era 21 dengan blended learning. Jurnal Kajian Teknologi Pendidikan, 1 (1), 13-18. 